\title{
Universiteit
}

Leiden

The Netherlands

\section{Provenance reinterpretation of some early Egyptian copper alloy artefacts}

Rademakers, F.W.; Verly, G.; Delvaux, L.; Degryse, P.A.I.H.

\section{Citation}

Rademakers, F. W., Verly, G., Delvaux, L., \& Degryse, P. A. I. H. (2021). Provenance reinterpretation of some early Egyptian copper alloy artefacts. Journal Of Archaeological Science-Reports, 38. doi:10.1016/j.jasrep.2021.103095

Version: $\quad$ Accepted Manuscript

License: $\quad$ Creative Commons CC BY-NC-ND 4.0 license

Downloaded from: https://hdl.handle.net/1887/3256975

Note: To cite this publication please use the final published version (if applicable). 


\section{Provenance reinterpretation of some early Egyptian copper alloy artefacts}

Frederik W. Rademakers, Georges Verly, Luc Delvaux, and Patrick Degryse

\section{Abstract}

We present a new provenance evaluation of recently published Egyptian copper alloy artefacts dating to the Protodynastic and Old Kingdom periods. The excavation context of a Protodynastic chisel from Elkab is considered in detail to provide a nuanced interpretation of its dating and its implications with regards to early Egyptian copper provenance. Furthermore, several Old Kingdom artefacts are discussed, some of which represent some of the earliest attestations of likely metal imports within Egypt. Using a broad range of reference data and technological arguments, alternative interpretations are suggested to obtain a more nuanced picture of copper alloy imports and their role in early Egyptian metal procurement.

\section{Dating a chisel from Elkab: Protodynastic or Old Kingdom?}

A chisel from Elkab, an Upper Egyptian site south of Luxor, was analysed by Rademakers et al. (2018). It is made of arsenical copper and its lead isotope (LI) ratios broadly match those of Southern Sinai copper ore deposits (for further details on its composition, see Rademakers et al. 2018). However, its exact dating was recently questioned, with implications for its provenance interpretation. Therefore, we revisit it here.

The chisel (shown in Figure 1) was excavated in 1955 by Gilbert, Mekhitarian and De Wit, as part of the Elkab mission under the auspices of the (then) Fondation Égyptologique Reine Élisabeth and the Royal Museums of Art and History (RMAH), Brussels. It was found within a large storage facility, more specifically in "Silo L".

Assigning a date to a museum artefact is not always straightforward and inevitably a difficult task despite careful study. The detailed reconstruction of the archaeological contexts of metal artefacts in the Egyptian collection of the RMAH has been one of the core aims of the EACOM project. Analytical studies by Rademakers et al. (2018, 2021, in preparation) are an important part of this project, but would not have been possible without the detailed collection research underlying it. Original museum entry files for all metal artefacts within the Egyptian collection have been revisited and only objects for which contextual data could be validated were targeted for further analysis.

In this regard, the work by Georges Verly, supported by Luc Delvaux, has been vital. For each of the artefacts analysed by Rademakers et al. (2018), they have rigourously researched the original excavation reports and ensuing publications. A summary of these research results is provided for each analysed artefact in the Supplementary Materials to Rademakers et al. $(2018,2021)$. For the dating of the Elkab chisel (E.09225), the authors made up the balance of all available evidence. The full nuance of this exercise was omitted and intended for later publication (cfr. Rademakers et al. 2018, p. 176).

The recent questioning of our proposed dating by Odler et al. presents a welcome opportunity to move this discussion forward. It has prompted us to revisit the contextual attribution of the Elkab chisel again 
with Wouter Claes, current director of archaeological excavations of Elkab et Faculty Member of the Department of Antiquities, RMAH. We summarise here the available evidence for dating this artefact.

In preparation of the 2018 publication, we worked with the late Dr. Dirk Huyghe, director of archaeological excavations of Elkab and Curator of Prehistoric and Early Dynastic Egypt at the RMAH, consulting the original 1937-1955 excavation notes (unpublished, held at the RMAH: Gilbert, Mekhitarian and De Wit 1955). The excavators initially dated the entire storage complex to the $1^{\text {st }}$ Dynasty period, yet this dating is difficult to validate, especially for silo $L^{1}$. In their evaluation of the storage site, Hendrickx and Eyckerman (2009) propose an overall dating for the complex wherein this silo was situated, but not for each of the individual silo's. It is important to note that silo $L$ is not discussed specifically by Hendrickx and Eyckerman, who are in fact uncertain of its location. Based on the finds associated with the chisel, specifically in Silo L (further documentation of the "large broken jar" ("grand vase brisé") is not available, but it was dated to the "Archaic period" $-1^{\text {st }}$ and $2^{\text {nd }}$ Dynasties - by the excavators), and its common typology, a $1^{\text {st }}$ Dynasty dating for the chisel was proposed by the EACOM team. Dr. Dirk Huyghe validated this possibility, without extending this dating to silo $L$ itself. Indeed, it can be noted that artefacts dating to the Predynastic and even the Badarian period were encountered in these silo's and it is likely that many of these artefacts were reused over time (Hendrickx and Eyckerman 2009). Hendrickx and Eyckerman (2009) include the chisel in their catalogue (p. 27) and further note (p. 16) that the chisel is of a very common type, which occurs from the $1^{\text {st }}$ Dynasty onwards (Spencer 1980).

An alternative approach is to date the silos themselves. This does not ensure a dating of the artefacts, but it does provide a terminus ante quem for the chisel. Wouter Claes (pers. comm.) notes that the silo complex is part of a settlement for which relatively little $1^{\text {st }}$ Dynasty material has been excavated, although the excavation area is limited (cfr. Rowland et al. 2009). Hendrickx and Eyckerman (2009) propose a generalized dating for the silo complex on the basis of the most abundant finds, which can be dated to the early Old Kingdom (although many artefact types occur earlier already). They conclude that an overall $3^{\text {rd }}$ Dynasty dating can be presumed. Nevertheless, the use of these silo's is likely to go back at least to the late $2^{\text {nd }}$ - early $3^{\text {rd }}$ Dynasty, as suggested for example by the ceramic remains as well as seal impressions from other silo's on site (near the temple: Regulski 2009). These silo complexes (similar to those encountered at Giza: Rowland et al. 2009) and their associated finds exemplify a growing economic role played by Elkab from the Predynastic period onwards as a provincial center. This is reflected by its active

\footnotetext{
${ }^{1}$ Gilbert, Mekhitarian and De Wit 1955: "Jeudi 20 janvier 1955 : Gilbert et Mekhitarian déterminent la ligne de départ de la fouille, à $5 \mathrm{~m}$ au sud des silos où ont été trouvés les scellés d'argile attribués par $M$. van de Walle à la première dynastie. Samedi 29 janvier 1955 : Il y aurait donc eu une certaine évolution entre le type du silo de Saqqarah Nord et celui d'Elkab. D'autre part tous nos types de poterie sont ceux de la pleine époque protodynastique. Il semblerait par conséquent assez probable que nos silos aient été construits au milieu de la période thinite et soient restés en usage au moins jusqu'au règne de Snéfrou. Un certain provincialisme ayant pu d'ailleurs maintenir à Elkab des formes un peu retardataires, il se pourrait que cette date dût être un peu abaissée. Lundi 31 janvier 1955 : Ils font l'aprèsmidi, avec De Wit, le tour des murs courbes d'ElKab, que Lauer attribue comme nous le faisons à l'époque prédynastique. Décidément les silos sont du début de la 1ère dynastie. Jeudi 3 février 1955 : Dans le silo L, de la rangée Nord, on sort un ciseau à froid en cuivre, assez près du fond, au niveau d'un fond écrasé de très large vase en terre rouge épaisse. [238] Ciseau à froid - 5 février 1938 - Cuivre. Carnet $n^{\circ} 184$ : ciseau à froid, en cuivre. Du silo L, au niveau du grand vase brisé. Dans le silo L, au niveau du grand vase brisé. Date: archaïque - cl. proj. 13.837. Album $n^{\circ} 116$ retrouvée mais non inventoriée au Musée, armoire Elkab K.238. Déblais de la région des silos - carnet $n^{\circ} 184$ $=K .238^{\prime \prime}$.
} 
institutions with representatives of the central administration being based at Elkab and elsewhere (Regulski 2009), and by the growing settlement complexity as a whole (Rowland et al. 2009).

With regards to chisel E.09225, Odler et al. (2021, p. 5) state that "Among the recently published objects is an adze/chisel blade from el-Kab made of arsenical copper, dated within the analytical study to the Dynasty 1, although it was isotopically more similar to Dynasty-3 objects from Bet Khallaf, made of Sinaitic ore (Rademakers et al., 2018b, p. 179). Dating of the archaeological context from the original publication to the break of Dynasties 3-4 ought to be followed (Hendrickx and Eyckerman, 255 2009)."

As far as contextual attribution is concerned, the discussion above shows that it is more complex than suggested by Odler et al. Regardless of the dating of the silo complex and even the individual silo L, the dating of the chisel itself, and specifically its production, is of importance here. The suggested dating by Odler et al. to the $3^{\text {rd }}-4^{\text {th }}$ Dynasty transition is incoherent with the overall $3^{\text {rd }}$ Dynasty dating of the complex proposed by Hendrickx and Eyckerman (2009), and no arguments in its favour exist. In fact, based on the available data as presented above, we maintain that a date preceding the $3^{\text {rd }}$ Dynasty is highly likely. Its attribution to the $1^{\text {st }}$ or $2^{\text {nd }}$ Dynasty is debatable, in terms of its production as well as its reuse and deposition, and unlikely ever to be resolved. Based on the available evidence, we therefore maintain the $1^{\text {st }}$ Dynasty dating as validated by Dr. Dirk Huyghe, while leaving open the possibility of a $2^{\text {nd }}$ Dynasty production date. Regardless, it should be situated in the Protodynastic period.

\section{Interpreting LI ratios for early Egyptian copper alloys}

The above contextual discussion has further bearing on the provenance interpretation of early Egyptian copper alloy artefacts. In this section, we suggest some further nuance to recent interpretations offered by Odler et al. (2021) for Old Kingdom artefacts from Giza, and that of the Elkab chisel discussed above.

In support of their suggested dating of artefact E.09225, Odler et al. (2021) note the isotopic similarity of the Elkab object with $3^{\text {rd }}$ Dynasty artefacts from Bet Khallaf published by Rademakers et al. (2018) - who already identified and discussed this similarity. Odler et al. state that the object is dated to the $1^{\text {st }}$ Dynasty "although it was isotopically more similar to Dynasty-3 objects from Bet Khallaf, made of Sinaitic ore (Rademakers et al. 2018b, p. 179)". We highlight this statement here, as it raises some important issues.

The correspondence in terms of $\mathrm{LI}$ ratios between two artefacts is a post-excavation observation. Odler et al. suggest that it may be used to infer (and dispute) the dating and context of an artefact. However, geochemical data should be evaluated in light of the artefact context, to be researched in detail in its own right. While some analytical results may urge us to revisit contextual data (for example, the hypothetical finding of a leaded gunmetal in a Predynastic context should invite serious doubt), isotopic similarity does not prove an adequate tool to this end (here).

Rademakers et al. (2018) note that the LI ratios of the Elkab chisel fall in the same broad range as those of $3^{\text {rd }}$ Dynasty Bet Khallaf artefacts, while they are not all the same in terms of elemental composition. The combination of elemental and $\mathrm{LI}$ ratio data for the interpretation of each individual artefact is of course fundamental towards a nuanced discussion of provenance ${ }^{2}$. Furthermore, some other Dynasty 1-

\footnotetext{
${ }^{2}$ We stress here again the importance of lead concentration data in the interpretation of LI ratios for early Egyptian copper alloys. Rademakers et al. (2017) noted this in the context of New Kingdom copper and the potential detection of mixing and alloying. We further highlighted its necessity in the context of possible copper ore source identification and the identification of arsenic alloying in early Egypt (Rademakers et al. 2018). This is emphasized because of the
} 
2 objects fall within this same $\mathrm{LI}$ range as the Bet Khallaf artefacts. This indicates that $\mathrm{LI}$ ratios do not provide a valid tool for dating early Egyptian artefacts, as further suggested by abundant evidence of mining in Sinai throughout Egyptian history. Rather, geochemical data allow us to explore the continuity and change in copper provisioning over time (cfr. Rademakers et al. 2018, p. 185).

With regards to provenance attributions, a nuanced approach and language are essential. For example, Rademakers et al. $(2018$, p. 179, 184) state that LI ratios for E.09225 "broadly match Southern Sinai ore data" and "a Southern Sinai ore provenance appears likely" - not that it was "made of Sinaitic ore" (Odler et al. 2021, p. 5). This distinction is subtle but essential. LI ratios of artefacts may correspond to those of ore deposits, but that does not prove that they were made from those ores. This basic tenet for LI ratio provenance analysis has been repeated ad nauseam over the past decades and is not elaborated here (see our position w.r.t. the specific case for ancient Egyptian copper in Rademakers et al. 2017, 2018, 2020, 2021). It is crucial to be precise and sufficiently nuanced in our interpretations of complex provenance data, as evidenced by discussions on LI ratio studies in the past (e.g., Gale 2009 and Pollard 2009 and references therein). This is particularly important in the context of a recent increase in archaeometallurgical studies within Egyptian archaeology, where many colleagues may yet need to be convinced of its utility (as noted by Odler et al. 2021, p. 8).

Copper provenance interpretations on the basis of trace element and $\mathrm{LI}$ ratio data require an explicit consideration of metallurgical technology, in this case accounting for the specificity of Egyptian metal production modes. This includes possible influences from smelting (cfr. Rademakers et al. 2020, 2021) which may introduce a small but relevant shift in LI ratios between those of ores and raw copper. Furthermore, secondary processes, such as alloying, may further shift LI ratios along a mixing line with raw copper and the alloy constituent as end members (the shift being relative to each constituent's lead contribution). The case for arsenic alloying during the Predynastic to Old Kingdom period was previously made by Rademakers et al. (2018) and extended for the Middle Kingdom period by Rademakers et al. (2021) on the basis of LI ratio and trace element data (cfr. Verly and Rademakers (forthcoming) for other lines of evidence). While Kmošek et al. (2018) do not explain elevated arsenic concentrations in early Egyptian copper, Odler et al. (2021, p. 8-9) seem to adopt our reasoning in full (not reiterated here).

In the context of evaluating the provenance of several Old Kingdom artefacts from Giza, Odler et al.'s (2021) subtitle "Ore origin - lead isotope ratios" belies an expectance for direct correspondence between ore (and production waste) and artefact LI ratios. Furthermore, they seem to expect a priori that their geochemical data should present a rather uniform distribution or homogeneous reflection of a particular (ore) source. However, there is no reason to assume ${ }^{3}$ that the metal of which these artefacts was made derives from a single source or source region (even if this may be case). This perspective is similarly

apparently low lead content of copper ores in Sinai (Abdel-Motelib et al. 2012, Pfeiffer 2013, Rademakers et al. 2018, 2020, 2021) - frequently (far) below the detection limits reported by Kmošek et al. (2018) and Odler et al. (2021) for lead $(1000$ and $500 \mu \mathrm{g} / \mathrm{g})$. This is most likely due to their use of very small samples: $30-50 \mu \mathrm{g}$ or less. Lutz and Pernicka (1996) note that samples of ca. $50 \mu \mathrm{g}$ are required to obtain a sample penetration equivalent to "infinite thickness" for XRF to avoid underestimation of some elements. Furthermore, smaller sample mass leads to higher detection limits. While curatorial considerations should of course be taken into account when sampling, one should consider if it is worth sampling artefacts if insufficient material can be obtained for a full characterization including LI ratios (cfr. Odler et al. 2021, p. 7).

${ }^{3}$ Especially given that these Giza artefacts derive from a settlement dump likely representing a mixed deposit over a period of time. 
revealed by the assemblage trend line proposed by Odler et al. (2021, Figure 6), which is strongly dominated by outlier G29. As such, this "ore origin" leaves little space for nuance ${ }^{4}$, which we would argue is due here.

A comparison to earlier published data reveals, inter alia, a high similarity (but no overlap) in terms of (highly radiogenic) LI ratios between a $3^{\text {rd }}$ Dynasty axe from Bêt Khallaf (E.00914a: Rademakers et al. 2018) and outlier G29 (a needle: Odler et al. 2021), although they differ markedly in terms of arsenic, silver, antimony and nickel concentrations (cobalt and selenium concentrations are comparable). This variability may infer variations within the Sinai deposit from which this metal was probably produced and the process by which they were smelted, and/or represent variation introduced through alloying (arsenic, antimony, lead concentrations - cfr. Rademakers et al. 2018, 2021). G13 represents another outlier in the Giza assemblage, both in terms of $\mathrm{LI}$ ratios and elemental composition, and is discussed further below.

G24 (no LI ratios determined) is remarkable for its tin concentration of almost $0.3 \%$ (not discussed by Odler et al.). Such tin concentrations significantly exceed those encountered in Sinai copper ores (relative to copper) or raw copper, as well as in most Protodynastic and Old Kingdom copper (cfr. Rademakers et al. 2021). A counterpart can be found in the $5^{\text {th }}-6^{\text {th }}$ Dynasty artefact 2600 from Giza (Kmošek et al. 2018: LI ratios interpreted as likely Eastern Desert provenance ${ }^{5}$ ), which similarly contains ca. $1 \%$ arsenic, $0.3 \%$ tin. Yet the elevated tin concentration remains unexplained: generally considered too low to represent an intentional alloy, it may point to the exploitation of a particular ore source (no comparable data for the Eastern Desert is available) or, perhaps more likely in this context, the recycling and mixing of tin bronze at some point in the production chain. This deviation from the rest of the assemblage is thus worth highlighting as its technological interpretation should be integrated in discussions of provenance.

The Giza artefacts are not compared in detail to other published artefact data by Odler et al. For example, in the discussion of trace elements they state that "Similarities are also visible with some Dynasty-3 artefacts from Bêt Khallaf (No. E.00915a-e, E.00916b-d, E.009157a-c, E.00918, E.01961c), proposed to come exclusively from Sinai (Rademakers et al. 2018)", yet this close similarity is not explored in terms of $\mathrm{LI}$ ratios. The point here is not to find exact ore sources. Rather, similarities (and thus possible continuity)

\footnotetext{
${ }^{4}$ Kmošek et al. (2018) do discuss provenance interpretation in more detail.

${ }^{5}$ Odler et al. (2021, p. 9) note that provenance discussions w.r.t. Eastern Desert ores are problematic, with Rademakers et al. (2018) "building heavily on only one article" for their characterisation. Like Kmošek et al. (2018), we include Eastern Desert evidence for copper extraction reported by Abdel-Motelib et al. (2012). We are aware of the Eastern Desert galena samples reported by Stacey et al. (1980), Stos-Gale and Gale (1981) and Brill et al. (1974) and evaluate these as background data. It is important to note, however, that (especially supergene) copper deposits do not necessarily share the same LI ratios, which is why these are treated with caution (cfr. Rademakers et al. 2017, pp. 57-60; 2018, p. 177) and not plotted in our LI ratio graphs. Similarly, galena used as kohl are interpreted to have an Eastern Desert provenance by Brill et al. (1974), Stos-Gale and Gale (1981) and Shortland (2006). We do not contest these interpretations, but treat $\mathrm{kohl}$ as a separate artefact category for provenance comparisons, and again with reservation w.r.t. copper production. As such, we follow the same approach as Odler et al. (2021), be it perhaps with more caution. The asserted wider range of available Eastern Desert copper ores remains to be characterised (e.g., Castel et al. (1998) mention that oxidic, as well as sulphidic ores may have been exploited during the Old Kingdom), including that of arsenopyrite. Zoheir et al. (2019), cited by Odler et al. in this context, discuss the mining of gold and present no clear archaeological indications for the extraction and processing of arsenopyrite.

${ }^{6}$ Here too we must emphasise that our provenance interpretations are more nuanced (cfr. discussion by Rademakers et al. 2018, pp. 183-184).
} 
in the composition of copper over time are noteworthy (in this case $3^{\text {rd }}$ Dynasty Bêt Khallaf and $4^{\text {th }}$ Dynasty Giza).

In order to assess these production and consumption systems over time, broad trends must be assessed without losing sight of the individual artefacts. For this reason, we expressly focus on the characteristics of individual artefacts, before expanding into comparisons within and across contexts and time periods. In this regard, it is helpful to consider the number of copper alloy artefacts for which both LI ratio and trace element data have been determined so far for the Predynastic to the end of the Old Kingdom periods, a timeframe spanning over two millennia: 11 artefacts from Maadi, Sheikh Mukhsen and Northern Sinai (Abdel-Motelib et al. 2012 and references therein), 13 from Tell el-Farkha ${ }^{7}$ (Rehren and Pernicka 2014), 40 from various sites (Rademakers et al. 2018), 15 from various sites (Kmošek et al. 2018), 10 from Giza (Odler et al. 2021), 1 from Kafr Hassan Dawood (Hassan et al. 2015) and 3 Nubian A artefacts (Anfinset 2010). These 93 objects (and counting), many of them tiny, can hardly be expected to cover the variability in copper alloys circulating across ancient Egypt over a period of more than 2000 years. Rather than expecting homogeneity or a full overview of the existing variation, we should expect to be looking at a tiny sample of a very varied landscape.

\section{The import of copper alloys during the Protodynastic and Old Kingdom periods: "invisible connections"}

\section{The problematic interpretation of a silver-arsenic-copper alloy from Giza}

In their overall discussion of the Old Kingdom Giza artefacts Odler et al. (2021) attribute relatively high importance to outliers in their assemblage ${ }^{8}$. We agree with them and Ben-Yosef (2018) that the revelation of unexpected compositions and possible "invisible connections" constitutes an important aspect of analytical studies. Arguably, the identification and explanation of long-term mining and metallurgical practices within Egypt represents a more fundamental contribution to be obtained from archaeometallurgical studies. Nonetheless, the identification of possible (long-distance) exchange is another key aspect. We would argue that this too requires some more nuance, however, ideally supported by "observable connections".

As noted by Odler et al., the composition of Giza needle G13 differs from any previously published Egyptian copper alloy artefact. With its combined silver and arsenic content of ca. 4.5\%, it would have had a somewhat silvery-orange appearance (cfr. Mödlinger et al. 2017). It is unclear, however, if the ancient Egyptian craftspeople would have distinguished this from "plain" arsenic alloys with $>2 \%$ arsenic. In fact, the artefact's typology and find context may argue against this, suggesting it fell within a common "perceptive category" (Mödlinger et al. 2017). While this constitutes a remarkable alloy type, similar contemporary (often natural) alloys from the broader ancient world are not discussed in detail by Odler et al. beyond a cursory reference to Near Eastern and Anatolian artefacts discussed by Horejs et al. (2010). Instead, they suggest the three following interpretations.

First, the possible production through direct smelting of silver-rich copper ores in Egypt is considered. However, no hitherto characterized deposits in Sinai or the Eastern Desert fit such a scenario. As admitted

\footnotetext{
${ }^{7}$ Only indicative XRF analysis is reported for the Tell el-Farkha artefacts.

${ }^{8}$ See similarly Kmošek et al. (2018, p. 199): "The most interesting and remote Group G1 comprises only a single vessel from Abusir (2162)".
} 
by Odler et al., the evidence to suggest ancient exploitation at Umm Semiuki is intriguing but sadly limited ${ }^{9}$ (see also Rademakers et al. 2021). Furthermore, no evidence has been published for the extractive metallurgy of sulphide (copper) ores in early Egypt. As such, this suggestion remains highly speculative and impossible to substantiate for now.

As a second explanation, the mixing of an arsenic copper alloy with (native) silver is suggested. One could wonder why (3\%) silver would be intentionally added to an arsenical copper alloy (or such an alloy selected) for the purpose of making a needle, and some further discussion by Odler et al. on how such a composition is to be understood in this context would be helpful ${ }^{10}$. Even if a progressive mixing scenario is envisaged, whereby the needle was the result of a final mixing or simple recycling step, the suggested initial selection of raw materials would represent a peculiar (intentional?) selection needing to be explained.

The third explanation (and "proposed solution") is far-fetched and highly problematic - yet it features as a headline in Odler et al.'s (2021) abstract. They propose a connection between G13 and Predynastic lead and aurian silver artefacts on the one hand, and late Uruk silver on the other hand, but this is not supported by the available data.

As a pure lead artefact, the hawk model is a curious point of comparison, as is the aurian silver artefact which represents a very different alloy type ${ }^{11}$ (reference to Helwing (2014) does not explain how they could be connected technologically). Furthermore, these artefacts predate the Giza assemblage by ca. 800-1000 (!) years. Additionally, the LI ratios of lead hawk model 1895.137 and aurian silver jar rim QC 1123 (Stos-Gale and Gale 1981) are clearly distinct from those of artefact G13: their LI ratios differ by ca. 0.5-1\% (5-10 times the accepted accuracy for LI provenance research: Stos-Gale and Gale 2009, Pernicka 1992) and there is no linear correlation between them. This difference is clearly visible in Odler et al. (2021, Figure 8), and illustrated here in Figures 2-3. As such, there is no observable connection between these two artefacts and artefact G13 from any perspective.

Regardless, Odler et al. state that the "cluster becomes denser when we include a litharge ... found at a late Uruk site". Odler et al.'s Figure 8 shows a range of LI ratio data that cover an enormous geological time scale. At that scale, and especially when plotting less sensitive LI ratios to ${ }^{206} \mathrm{~Pb}$, even disparate data may appear clustered. However, looking at the data at a more reasonable scale, and by evaluating all $\mathrm{LI}$ ratio data (incl. ${ }^{208} \mathrm{~Pb} /{ }^{204} \mathrm{~Pb}$, cfr. Figures $2-3$ ), it is evident that the litharge data and G13 do not overlap (relative distance in the ${ }^{206-207} \mathrm{~Pb} /{ }^{204} \mathrm{~Pb}$ ratios is ca. 3 times the accepted accuracy), nor do they lie on a

\footnotetext{
${ }^{9}$ Apart from arsenic and silver, antimony and particularly zinc may be elevated in the malachite deposits at Umm Semiuki (Shalaby et al. 2004). As such, an incidental production of arsenic- and silver-rich copper with $<10 \mu \mathrm{g} / \mathrm{g}$ zinc may be an even less likely scenario. Afia (1985) already suggested Umm Semiuki as a possible source for Predynastic copper with percentage-levels of zinc. Obviously, the Umm Semiuki deposit should not be used as a panacea to explain any aberrant Egyptian copper alloy without further supporting evidence.

${ }^{10}$ The alloying of silver with copper attested in Mesopotamia (e.g., Pernicka 1993), albeit in different proportions, may represent an interesting counterpart. It does not, however, explain the selected alloy for this needle.

${ }^{11}$ For comparison: two Protodynastic pieces of jewelry from the Ashmolean Museum collection, analysed by StosFertner and Gale (1979), consist of copper alloys with 3.7 and 12.5\% silver. However, these further include 4.4 and $4.1 \%$ gold respectively, and no arsenic. As such, these represent an altogether different alloy type: an outlier in the tradition of gold/silver/electrum alloying with copper. The Predynastic aurian silver mount discussed by Odler et al., with $4.9 \%$ copper, $61.4 \%$ silver and $33.7 \%$ gold (Oxalid database), falls within this tradition.
} 
trend or mixing ${ }^{12}$ line (with either G13 or the Predynastic artefacts). Therefore, no clustering or any other relation can be inferred between these data.

Production at Habuba Kabira concerns silver cupellation, the product of which would have been highly pure silver (Nezafati and Pernicka 2012). As such, litharge should not be expected automatically to form a logical cluster with lead and aurian silver artefacts, nor with a Ag-As-Cu alloy. One should consider what the $\mathrm{LI}$ ratios of the latter represent: if silver was intentionally added to the G13 alloy, which is very debatable, the lead contribution is expected to be small and LI ratios of the silver and alloy should not be expected to correspond. Indeed, lead concentrations in cupelled silver are typically above ca. $200 \mu \mathrm{g} / \mathrm{g}$ (Pernicka 1987) but usually does not exceed 0.05 wt\% (Pernicka et al. 1990) to 0.5 wt\% (Stos-Gale 2014). In a copper alloy with 3 wt\% silver, the absolute lead contribution from the silver would be ca. 60 to 1600 $\mu \mathrm{g} / \mathrm{g}$. As such, its lead contribution may well be obscured by that of the other alloy constituents. Odler et al.'s reported lead detection limits are too high to explore this further for G13.

Even if an LI ratio overlap between G13 and Habuba Kabira litharge existed (which the available data do not show), the question would be whether or not such a match makes sense when taking into consideration the elemental composition of the artefact, its production technology and the wider archaeological context. The fact that Odler et al. rely on LI ratios alone in their comparison to Habuba Kabira, without discussion of this technological perspective or wider implications of this interpretation, is problematic. The question of how such an alloy would have been made (cfr. above) stands to be explained. Furthermore, there is a chronological time gap of ca. 1000 years between silver production at Habuba Kabira and artefact G13's deposition, rendering any connection highly tenuous and in need of substantial proof.

In summary, Odler et al.'s proposed hypothesis of an "invisible connection" to Habuba Kabira is not supported by the available data. The suggested long-distance connection through a millennium of recycling is not convincing at all: the burden of proof for such an exceptional claim is not met by the authors. Their admittance that "The case is not strong enough" does not excuse its inclusion, as such interpretations are too easily picked up and perpetuated.

\section{Alternative explanations for "foreign metals" found at Abusir and Giza}

Given the considerations above, alternative explanations for Giza needle G13's composition should be suggested ${ }^{13}$. In this section, we offer a broader review of available reference data to suggest alternative production and provenance hypotheses for this peculiar artefact, and for another unusual $1^{\text {st }}$ Dynasty artefact from Abusir published by Kmošek et al. (2018). Rather than starting from complicated mixing and recycling scenarios, data for contemporary copper alloys as well as exploited ore sources from which silver-arsenic-copper alloys might be co-smelted are considered in the first instance.

\footnotetext{
${ }^{12}$ A mixing scenario involving more than two end members could be suggested - yet this opens the floor to a huge number of scenarios, amidst which the suggested hypothesis does not merit special consideration. Indeed, resolving such mixing scenarios is beyond the resolution of currently available methods.

${ }^{13}$ Odler and Kmošek (2020, p. 132) note that needle ÄMUL 2216 has similar LI ratios to G13, yet the ratios to ${ }^{204} \mathrm{~Pb}$ differ by ca. 0.8-1.2\% and are thus clearly distinct. Furthermore, ÄMUL 2216 does not have percentage level arsenic or silver concentrations, but relatively higher lead (ca. $0.25 \%$ ). As such, there is little similarity between these two artefacts. Confusingly, Odler and Kmošek (2020, p. 132) attribute an Eastern Desert provenance to G13 (with reference to Odler et al. 2021), most likely referring to Umm Semiuki (cfr. above).
} 
Published data on ores and alloys from the Persian Gulf, Anatolia and Crete provide no perfect matches ${ }^{14}$ in terms of $\mathrm{LI}$ ratios and elemental composition for G13. Connections between Egypt and the Levant are attested from the Predynastic period onwards, for example at Maadi (Abdel-Motelib et al. 2012, Pfeiffer 2009), but available EBA copper data (often matching Arabah Valley ores, e.g., Hauptmann et al. 2015, Philip et al. 2003, Segal et al. 1999) differ strongly from G13. More relevant perhaps are some EBA Cycladic artefacts (e.g., 11/L6.320 and 53/L3.822: Kayafa et al. 2000) which have similar (not identical) LI ratios, and elevated (although lower) silver concentrations. Rivet ${ }^{15}$ 81/L5.846 (Kayafa et al. 2000) has slightly more divergent $\mathrm{LI}$ ratios (though still in a similar range) but ca. $5 \%$ silver and $2.4 \%$ arsenic (and $0.2 \%$ tin). As such, the Cyclades may offer an interesting comparative. Kayafa et al. (2000) point to the polymetallic ores of Siphnos on the basis of $\mathrm{LI} \mathrm{ratios}^{16}$, while Kythnos (see Stos-Gale 1989) may represent another possible source candidate (although high silver concentrations - unlike arsenic- are not reported there by Bassiakos and Philaniotou (2007) or Gale et al. (1985)). When adopting a timescale of 1000 years (as Odler et al.), one could even make a comparison to the $\mathrm{Cu}-\mathrm{As}-\mathrm{Sb}(-\mathrm{Ag}-\mathrm{Ni})$ alloy artefacts of the Nahal Mishar hoard (Tadmor et al. 1995) as representatives of natural polymetallic alloys circulating in the Levant. While no overlap exists between the LI ratios of G13 and the wide range exhibited by this hoard (Figures 2-3), the relative difference is even slightly smaller than for the Habuba Kabira material ${ }^{17}$.

We do not think it is possible at this stage to resolve the provenance of artefact G13 with certainty. However, we note that comparisons to the wider literature may be able to reveal alternative "invisible connections" and illuminate the reality of various possible interpretations. It should be emphasized that the $\mathrm{LI}$ ratios of this particular artefact may not directly reflect those of a single ore deposit if it is indeed the result of an alloying/mixing process rather than direct smelting (as noted by Odler et al.). In this instance, it would be particularly helpful to know the artefact's precise lead concentration to evaluate possible mixing scenarios. Regardless, comparisons to other copper alloys offer a more secure and meaningful anchoring point for discussion of alloy composition from a "metal stock perspective" (cfr. Rademakers et al. 2021).

Similar to considerations made for G13, the attribution of an Anatolian origin to the $1^{\text {st }}$ Dynasty bowl 2162 (Kmošek et al. 2018) can be revisited and some nuance added. Kmošek et al. (2018, p. 204) claim to have "proof" for a connection between Egypt and Anatolia during the Early Bronze Age (see also Odler and

\footnotetext{
${ }^{14}$ For example, artefact G13's LI ratios fall within the broader range of artefacts from the Persian Gulf (Weeks 2003), although none of these artefacts have such high silver contents (Weeks 1997, 1999). Samples from Turkish ores from Bakir Dagi (no elemental data reported: Begemann et al. 2003), Esendemirtepe (no elemental match: Yener et al. 1991) and copper slag from Doğancilar (no elemental data reported: Begemann et al. 2003) too have similar LI ratios but their elemental composition is not consistent. Perhaps more interesting are some artefacts from Besiktepe (Begemann et al. 2003) which have similar LI ratios, and often elevated silver, but a strong overall match cannot be identified. Another interesting point of comparison may be Dagger M4 from Livari, Early Minoan IB Crete (GiumliaMair et al. 2018, 2020), although it is dated to 3000-2800 BCE and thus pre-dates G13 by several centuries (GiumliaMair et al. (2018) consider the elevated silver content a deliberate addition). G13's LI ratios further fall within the range of several other Cretan artefacts, which mostly have low arsenic and silver concentrations.

${ }^{15}$ Kayafa et al. (2000) consider it unlikely that silver was intentionally added to this rivet (and another silver-rich pin), but rather point to polymetallic ore smelting as an explanation (mainly on the basis of low tin, although the silver concentration fits this picture too). This reasoning can equally be applied to needle G13.

${ }^{16}$ Note that Vavelidis et al. (1985) report data on silver ores enriched in arsenic, copper, lead and zinc. Cu-Ag-As artefacts are not reported and would represent a very specific, and perhaps unlikely, outcome of smelting such ores. Nonetheless, Kayafa et al. (2000) consider this to have been possible at Siphnos.

${ }^{17}$ To be clear: we do not suggest that G13 and the Nahal Mishmar hoard artefacts share the same provenance.
} 
Kmošek 2020, pp. 25-26). This claim is presented on the basis of elemental data (the bowl is made of a $\mathrm{Cu}-\mathrm{As}-\mathrm{Ni}$ alloy) and $\mathrm{LI}$ ratios. Indeed, this alloy is again unlikely to represent a product from copper ores available in Egypt's mining zones (yet see ${ }^{18}$ Davey et al. 2021). However, Anatolia is not unique in producing such alloys. Importantly, the LI ratios of this artefact (2162) do not match exactly with any of the EBA Anatolian alloys of similar composition. While Kmošek et al. (2018, p. 204) state that "it has isotopic ratios and chemical composition very similar to some objects found in the so-called Royal Tomb at Arslantepe", similarity should be evaluated carefully here. As Figures 2-3 show, its LI ratios are quite distinct from those of the contemporary alloys (particularly evident when considering all LI ratios for the Arslantepe alloys and ore finds (Hauptmann et al. 2002) and Kfar Monash CuAsNi alloys and Maadi sample HDM 363 (Hauptmann et al. 2011)): these do not match in terms of LI ratios ${ }^{19}$. Furthermore, artefact 2162 falls on the very margins of the $\mathrm{LI}$ range defined by currently available Anatolian ore data (cfr. Kmošek et al. 2018, Figure 8). Kmošek et al. do not further pursue which specific ore types correspond to these particular LI ratios, nor whether the available geological data would support the hypothesis of Cu-As-Ni alloys being produced from them during this period. As such, it would be better practice to present this "proof" as a hypothesis. While it may be correct, this has not been shown at this point. Alternative comparisons, for example to EBA alloys and ores in the Aegean, should equally be explored.

In terms of artefact 2162's LI ratios (cfr. Figures 2-3), a better match can be found with copper ores from Lavrion (Gale et al. 2009), which are high in arsenic (although not reported for nickel). Another interesting comparative in this regard are again artefacts from the EBA Greece (Kayafa et al. 2000). Many have similar LI ratios, percentage levels of arsenic and elevated antimony, although mostly low nickel concentrations (an important exception is awl 29/L5.52 with 5\% nickel and 3\% arsenic, consistent with Lavrion in terms of $\mathrm{LI}$ ratios). These examples provide a better match in terms of $\mathrm{LI}$ ratios than the suggested Anatolian connection, even if their dating spans the third millennium BCE. Furthermore, the analysis of copper slag at Chrysokamino, Crete, revealed the production of copper with ca. $0.5-2 \%$ nickel (and up to $30 \%$ arsenic). In one slag prill, up to $15 \%$ nickel is measured (with $23 \%$ arsenic), but this appears to be exceptional. Nonetheless, the outcome was a Cu-As-Fe-Ni alloy (Bassiakos and Catapotis 2006). Again, some of the LI ratios of the Chrysokamino slag are consistent with Lavrion copper ores, while other slag matches slag and ore samples from Kythnos and Seriphos (Cyclades). Overall, Stos and Gale (2006) consider Lavrion and the Cyclades as the most likely source of copper for the Minoans, as reflected in analysed Minoan artefacts. As both Old Kingdom G13 (Odler et al. 2021) and $1^{\text {st }}$ Dynasty 2162 (Kmošek et al. 2018) fall within the range exhibited by Cretan artefacts (cfr. Oxalid database ${ }^{20}$ ) and Cycladic ores (and Lavrion ores for 2162), their discussion may be of interest - even if a perfect match is not found and many represent quite different alloys. While evidence for Minoan imports in Egypt is lacking for the Old Kingdom, contact

\footnotetext{
${ }^{18}$ Davey et al.'s (2021) findings were published online only a week before Odler et al.'s (2021) paper and were thus not available to them. They represent the crucible processing of a high arsenic-nickel copper alloy. While the crucible slag's increased iron concentration could be interpreted to reflect the melting of raw copper (see Rademakers 2015, pp. 186-189) and its alloying with arsenic, Davey et al.'s proposed direct co-smelting of a copper carbonate with elevated nickel and arsenic is perhaps more likely indeed. The latter could suggest the availability of copper ores compatible with 2162's composition in Egypt - either from deposits within Egypt or Nubia or obtained through longer-distance exchange.

19 Out of all this data, the Cu-As-Ni alloys represent the most reliable points of comparison. For all of these Arslantepe, Kfar Monash and Maadi alloys, at least one of the ratios to ${ }^{204} \mathrm{~Pb}$ differs by $0.4 \%$ or more (up to $2 \%$ ) compared to those of bowl 2162.

${ }^{20}$ At the time of writing, LI ratio data for 670 artefacts are included, mainly from Early to Late Minoan contexts. As such, it is a much larger database than available for, e.g., Egypt or Syria, causing significant bias.
} 
is attested in Crete (e.g., Phillips 1996). As such, the import of Minoan copper to Egypt could be an interesting "invisible connection" for which observable evidence can be gathered.

\section{Conclusion}

This paper has presented an in depth evaluation of the contested context of a Protodynastic chisel from Elkab. From this discussion, the broader scope for distinguishing the (geological) provenance of early Egyptian artefacts was elaborated, whereby specific attention has been drawn to the influence of both primary and secondary metallurgical processes and the need for evaluating copper alloys from the perspective of a circulating metal stock within Egypt. In the second part of the paper, the provenance of rare alloy types encountered in Protodynastic and Old Kingdom contexts has been reevaluated. Taking into account the full scope of available evidence, it is clear that unequivocal proof for a specific provenance cannot be given. For the case of an Old Kingdom Ag-As-Cu alloy from Giza, the proposed connection to late Uruk silver production was shown to be unsubstantiated. For a Protodynastic bowl from Abusir, the suggested Anatolian provenance can be questioned, with a Minoan connection possibly offering a better hypothesis. Overall, it is emphasised that such attributions remain tentative at the current state of research and nuance is essential.

\section{Acknowledgments}

We warmly thank Wouter Claes for his detailed discussion of the silo complex documentation and the dating of chisel E.09225.

\section{Figure captions}

Figure 1: Protodynastic chisel E.09225 from Elkab, held at the Royal Museums of Art and History, Brussels

Figure 2: Comparison of $\mathrm{LI}$ ratios for artefacts and ores discussed in this paper. Data for Anatolian ores from Hirao et al. (1995), Sayre et al. (2001), Seeliger et al. (1985), Wagner et al. (1985, 1986, 2003), Yener et al. (1991); data for Cycladic ores from Chalkias et al. (1988), Gale and Stos-Gale (1981), Gale et al. (1988), Stos-Gale (1989), Stos-Gale et al. (1996); data for Lavrion copper ores from Gale et al. (2009); data for Lavrion lead ores from Oxalid database (http://oxalid.arch.ox.ac.uk/); data for Arslantepe ore finds from Hauptmann et al. (2002)

Figure 3: Comparison of $\mathrm{LI}$ ratios for artefacts discussed in this paper. Data for Cretan artefacts from Oxalid database (http://oxalid.arch.ox.ac.uk/); data for Greek artefacts from Kayafa et al. (2000); data for Arslantepe artefacts from Hauptmann et al. (2002); data for Kfar Monash (and Maadi) artefacts from Hauptmann et al. (2011); data for Predynastic, Protodynastic and Old Kingdom alloys from Kmošek et al. (2018), Rademakers et al. (2018) and Odler et al. (2021); two Predynastic artefacts (1895.137 and QC 1123) from Stos-Gale and Gale (1981)

\section{References}

Abdel-Motelib, A., Bode, M., Hartmann, R., Hartung, U., Hauptmann, A., and Pfeiffer, K. (2012), Archaeometallurgical expeditions to the Sinai Peninsula and the Eastern Desert of Egypt (2006, 2008), Metalla 19, 3-59.

Afia, M.S. (1985), Mining in Egypt: Past and Present, Vol. 1, Cairo: EGSB. 
Anfinset, N. (2010), Metal, Nomads and Culture Contact: the Middle East and North Africa, London: Routledge.

Bassiakos, Y. and Catapotis, M. (2006), Reconstruction of the copper smelting process based on the analysis of ore and slag samples, in P.P. Betancourt, ed., The Chrysokamino Metallurgy Workshop and Its Territory, Athens: The American School of Classical Studies at Athens, pp. 329353.

Bassiakos, Y. and Philaniotou, O. (2007), Early copper production on Kythnos: archaeological evidence and analytical approaches to the reconstruction of the metallurgical process, in P.M. Day and R.C.P. Doonan, eds., Metallurgy in the Early Bronze Age Aegean, Oxford: Oxbow Books, pp. 19-56.

Begemann, F., Schmitt-Strecker, S. and Pernicka, E. (2003), On the composition and provenance of metal finds from Besiktepe (Troia), in G.A. Wagner, E. Pernicka and H.-P. Uerpmann, eds., Troia and the Troad: Scientific Approaches, Berlin, Heidelberg, New York: Springer, pp. 173201.

Ben-Yosef, E. (2018), Provenancing Egyptian metals: a methodological comment, Journal of Archaeological Science 96, 208-215.

Brill, R.H., Barnes, I.L. and Adams, B. (1974), Lead isotopes in some ancient Egyptian objects, in A. Bishay, ed., Recent Advances in Science and Technology of Materials, Band 3, New York: Plenum, pp. 9-27.

Castel, G., Köhler, E.C., Mathieu, B., and Pouit, G. (1998), Les mines du ouadi Um Balad (désert Oriental), Bulletin de l'Institut Francais d'Archéologie Orientale 98, 57-87.

Chalkias, S., Vavelidis, M., Schmitt-Strecker, S., and Begemann, F. (1988), Geologische Interpretation der Blei-Isotopen-Verhältnisse von Erzen der Insel Thasos, der Ägäis und Nordgriechenlands, in G.A. Wagner and G. Weisgerber, eds., Antike Edel- und Buntmetallgewinnung auf Thasos, Bochum: Deutsches Bergbau-Museum, pp. 59-74.

Davey, C.J., Santarelli, B. and Rehren, Th. (2021), Egyptian Middle Kingdom copper: analysis of a crucible from Buhen in the Petrie Museum, Journal of Archaeological Science: Reports 36, 102859.

Gale, N.H. (2009), A response to the paper of A. M. Pollard: What a long strange trip it's been: lead isotopes and archaeology, in A.J. Shortland, I.C. Freestone and Th. Rehren, eds., From Mine to Microscope. Advances in the Study of Ancient Technology, Oxford: Oxbow Books, pp. 191-196.

Gale, N.H., Kayafa, M. and Stos-Gale, Z.A. (2009), Further evidence for Bronze Age production of copper from ores in the Lavrion district, Attica, Greece, Archaeometallurgy in Europe 2007. Selected Papers of the 2nd International Conference 17.-21. June 2007 in Aquileia, Milan: Associazione Italiana di Metallurgia, pp. 158-176.

Gale, N.H., Papastamataki, A., Stos-Gale, Z.A., and Leonis, K. (1985), Copper sources and copper metallurgy in the Aegean Bronze Age, in P.T. Craddock and M.J. Hughes, eds., Furnaces and Smelting Technology in Antiquity, London: British Museum, pp. 81-101. 
Gale, N.H., Picard, O. and Barrandon, J.N. (1988), The archaic Thaisan silver coinage, in G.A. Wagner and G. Weisgerber, eds., Antike Edel- und Buntmetallgewinnung auf Thasos, Bochum: Deutsches Bergbau-Museum, pp. 59-74.

Gale, N.H. and Stos-Gale, Z.A. (1981), Cycladic lead and silver metallurgy, The Annual of the British School at Athens 76, 169-224.

Giumlia-Mair, A.R., Betancourt, P. and Ferrence, S.C. (2018), Arsenic in the network: arsenical copper in Minoan Crete, in A. Giumlia-Mair and F. Lo Schiavo, eds., Bronze Age Metallurgy on Mediterranean Islands. Volume in Honor of Robert Maddin and Vassos Karageorgis, DrémilLafage: éditions Mergoil, pp. 578-598.

Giumlia-Mair, A., Ferrence, S.C., Betancourt, P.P., and Muhly, J.D. (2020), Silver and silvery alloys in Early Minoan IB Crete, Materials and Manufacturing Processes 35, 1476-1483.

Hassan, F.A., Tassie, G.J., Rehren, Th. and van Wetering, J. (2015), On-going investigations at the Predynastic to Early Dynastic site of Kafr Hassan Dawood: copper, exchange and tephra, Archéo-Nil 25, 75-90.

Hauptmann, A., Schmitt-Strecker, S. and Begemann, F. (2011), Bronze Age Kfar Monash, Palestine - a chemical and lead isotope study into the provenance of its copper, Paléorient 37, 6578.

Hauptmann, A., Schmitt-Strecker, S., Begemann, F., and Palmieri, A. (2002), Chemical composition and lead isotopy of metal objects from the "Royal" tomb and other related finds at Arslantepe, Eastern Anatolia, Paléorient 28, 43-69.

Hauptmann, A., Schmitt-Strecker, S., Levy, T.E., and Begemann, F. (2015), On Early Bronze Age copper bar ingots from the southern Levant, Bulletin of the American Schools of Oriental Research $373,1-24$.

Helwing, B. (2014), Silver in the early state societies of Greater Mesopotamia, in H. Meller, R. Risch and E. Pernicka, eds., Metals of Power - Early Gold and Silver, Halle: Landesamt für Denkmalpflege und Archäologie Sachsen-Anhalt, pp. 411-421.

Hendrickx, S. and Eyckerman, M. (2009), The 1955 excavation of an early Old Kingdom storage site at Elkab, in W. Claes, H. De Meulenaere and S. Hendrickx, eds., Elkab and beyond: Studies in Honour of Luc Limme, Leuven: Peeters, pp. 1-30.

Hirao, Y., Enomoto, J. and Tachikawa, H. (1995), Lead isotope ratios of copper, zinc and lead minerals in Turkey in relation to the provenance study of artefacts, in H.I.H. Prince Takahito Mikasa, ed., Essays on Ancient Anatolia and its surrounding civilisations, Wiesbaden: Harrassowitz Verlag, pp. 89-114.

Horejs, B., Pernicka, E. and Mehofer, M. (2010), Metallhandwerker im frühen 3. Jt. v. Chr. - Neue Ergebnisse vom Çukuriçi Höyük, Istanbuler Mitteilungen 60, 7-37.

Kayafa, M., Stos-Gale, S. and Gale, N. (2000), The circulation of copper in the Early Bronze Age in Mainland Greece: the lead isotope evidence from Lerna, Lithares and Tsoungiza, in C.F.E. Pare, ed., Metals Make the World go Round: Supply and Circulation of Metals in Bronze Age Europe, Oxford: Oxbow Books, pp. 39-55. 
Kmošek, J., Odler, M., Fikrle, M., and Kochergina, Y.V. (2018), Invisible connections. Early Dynastic and Old Kingdom Egyptian metalwork in the Egyptian Museum of Leipzig University, Journal of Archaeological Science 96, 191-207.

Lutz, J. and Pernicka, E. (1996), Energy dispersive X-ray fluorescence analysis of ancient copper alloys: empirical values for precision and accuracy, Archaeometry 38, 313-323.

Mödlinger, M., Kuijpers, M.H.G., Braekmans, D., and Berger, D. (2017), Quantitative comparisons of the color of $\mathrm{CuAs}, \mathrm{CuSn}, \mathrm{CuNi}$, and $\mathrm{CuSb}$ alloys, Journal of Archaeological Science 88, 14-23.

Odler, M., Kmosek, J., Fikrle, M., Kochergina, Y.V.E. (2021), Arsenical copper tools of Old Kingdom Giza craftsmen: first data, Journal of Archaeological Science: Reports 36, 102868.

Pernicka, E. (1987), Erzlagerstätten in der Ägäis und ihre Ausbeutung im Altertum: Geochemische Untersuchungen zur Herkunftsbestimmung archäologischer Metallobjekte, Jahrbuch des Römisch-Germanischen Zentralmuseums Mainz 34, 607-714.

Pernicka, E. (1992), Evaluating lead isotope data, Archaeometry 34, 322-326.

Pernicka, E. (1993), Analytisch-chemische Untersuchungen an Metallfunden van Uruk-Warka und Kis, in M. Müller-Karpe, ed., Metallgefässe im Iraq I (von den Anfängen bis zur Akkad-Zeit), Stuttgart: Franz Steiner Verlag, pp. 312-316.

Pernicka, E., Begemann, F., Schmitt-Strecker, S., and Grimanis, A.P. (1990), On the composition and provenance of metal artefacts from Poliochni on Lemnos, Oxford Journal of Archaeology 9 , 263-298.

Pfeiffer, K. (2009), The technical ceramic for metallurgical activities in Tall Hujayrāt al-Ghuzlān and comparable sites in the southern Levant, in K. Schmidt and L. Khalil, eds., Prehistoric Aqaba $I$, Rahden/Westfalen: Verlag Marie Leidorf, pp. 305-388.

Pfeiffer, K. (2013), Neue Untersuchungen zur Archäometallurgie des Sinai. Die Entwicklungsgeschichte der Innovation "Kupfermetallurgie", Rahden/Wesfalen: Leidorf.

Philip, G., Clogg, P.W. and Dungworth, D. (2003), Copper metallurgy in the Jordan valley from the third to the first millennia BC: chemical, metallographic and lead isotope analyses of artefacts from Pella, Levant 35, 71-100.

Phillips, J. (1996), Aegypto-Aegean relations up to the 2nd millennium B.C., in L. Krzyżaniak, K. Kroeper and M. Kobusiewicz, eds., Interregional Contacts in the Later Prehistory of Northeastern Africa, Poznan: Poznan Archaeological Museum, pp. 459-470.

Pollard, A.M. (2009), What a long, strange trip it's been: lead isotopes and archaeology, in A.J. Shortland, I.C. Freestone and Th. Rehren, eds., From Mine to Microscope. Advances in the Study of Ancient Technology, Oxford: Oxbow Books, pp. 181-189.

Rademakers, F.W. (2015), Into the Crucible. Methodological Approaches to Reconstructing Crucible Metallurgy, from New Kingdom Egypt to Late Roman Thrace, Unpublished PhD Thesis, University College London, URI: http://discovery.ucl.ac.uk/id/eprint/1469615. 
Rademakers, F.W., Rehren, Th. and Pernicka, E. (2017), Copper for the Pharaoh: Identifying multiple metal sources for Ramesses' workshops from bronze and crucible remains, Journal of Archaeological Science 80, 50-73.

Rademakers, F.W., Verly, G., Delvaux, L., and Degryse, P. (2018), Copper for the afterlife in Predynastic to Old Kingdom Egypt: provenance characterization by chemical and lead isotope analysis (RMAH collection, Belgium), Journal of Archaeological Science 96, 175-190.

Rademakers, F.W., Verly, G., Delvaux, L., Vanhaecke, F., and Degryse, P. (2021), From desert ores to Middle Kingdom copper. Elemental and lead isotope data from the RMAH collection, Belgium, Archaeological and Anthropological Sciences, revised and resubmitted.

Rademakers, F.W., Verly, G., Somaglino, C., and Degryse, P. (2020), Geochemical changes during Egyptian copper smelting? An experimental approach to the Ayn Soukhna process and broader implications for archaeometallurgy, Journal of Archaeological Science 122, 105223.

Regulski, I. (2009), Early Dynastic seal impressions from the settlement site at Elkab, in W. Claes, H. De Meulenaere and S. Hendrickx, eds., Elkab and Beyond: Studies in Honour of Luc Limme, Leuven: Peeters, pp. 31-47.

Rehren, Th. and Pernicka, E. (2014), First data on the nature and origin of the metalwork from Tell el-Farkha, in A. Maczynska, ed., The Nile Delta as a Centre of Cultural Interactions between Upper Egypt and the Southern Levant in the 4th Millennium BC, Poznan, pp. 237-252.

Rowland, J., Maríková Vlcková, P., Hendrickx, S., Herbich, T., Claes, W., and Huyge, D. (2009), Old Kingdom settlement remains at Elkab (Upper Egypt). Preliminary report on the 2009 field season, Bulletin des Musées Royaux d'Art et d'Histoire 80, 21-50.

Sayre, E.V., Joel, E.C., Blackman, M.J., Yener, K.A., and Özbal, H. (2001), Stable lead isotope studies of Black Sea Anatolian ore sources and related Bronze Age and Phrygian artefacts from nearby archaeological sites. Appendix: new Central Taurus ore data, Archaeometry 43, 77-115.

Seeliger, T.C., Pernicka, E., Wagner, G.A., Begemann, F., Schmitt-Strecker, S., Eibner, C., Öztunali, Ö., and Baranyi, I. (1985), Archaeometallurgische Untersuchungen in Nord- und Ostanatolien, Jahrbuch des Römisch-Germanischen Zentralmuseums Mainz 32, 597-659.

Segal, I., Halicz, L. and Cohen, R. (1999), A study of ingots and metallurgical remains from `Ein Ziq and Be'er Resisim, Central Negev, Israel, in S.M.M. Young, A.M. Pollard, P. Budd, and R.A. Ixer, eds., Metals in Antiquity, Oxford: Archaeopress, pp. 179-186.

Shalaby, I.M., Stumpfl, E., Helmy, H.M., El Mahallawi, M.M., and Kamel, O.A. (2004), Silver and silver-bearing minerals at the Um Samiuki volcanogenic massive sulphide deposit, Eastern Desert, Egypt, Mineralium Deposita 39, 608-621.

Spencer, A.J. (1980), Catalogue of Egyptian Antiquities at the British Museum V. Early Dynastic Objects, London: British Museum Press.

Stacey, J.S., Doe, B.R., Roberts, R.J., Delevaux, M.H., and Gramlich, J.W. (1980), A lead isotope study of mineralization in the Saudi Arabian Shield, Contributions to Mineralogy and Petrology $74,175-188$. 
Stos, Z.A. and Gale, N.H. (2006), Lead isotope and chemical analyses of slags from Chrysokamino, in P.P. Betancourt, ed., The Chrysokamino Metallurgy Workshop and Its Territory, Athens: The American School of Classical Studies at Athens, pp. 229-319

Stos-Gale, Z.A. (1989), Cycladic copper metallurgy, in A. Hauptmann, E. Pernicka and G.A. Wagner, eds., Old World Archaeometallurgy. Proceedings of the International Symposium 'Old World Archaeometallurgy', Heidelberg 1987', Bochum: Deutsches Bergbau-Museum, pp. 279291.

Stos-Gale, Z.A. (2014), Silver vessels in the Mycenaean Shaft Graves and their origin in the context of the metal supply in the Bronze Age Aegean, in H. Meller, R. Risch and E. Pernicka, eds., Metals of Power - Early Gold and Silver. 6th Archaeological Conference of Central Germany, October 17-19, 2013 in Halle (Saale), Halle: Landesamt für Denkmalpflege und Archäologie Sachsen-Anhalt, pp. 183-208.

Stos-Gale, Z.A. and Gale, N.H. (1981), Sources of galena, lead and silver in predynastic Egypt, Revue d'Archéometrie 1, 285-296.

Stos-Gale, Z.A. and Gale, N.H. (2009), Metal provenancing using isotopes and the Oxford archaeological lead isotope database (OXALID), Archaeological and Anthropological Sciences 1, 195-213.

Stos-Gale, Z.A., Gale, N.H. and Annetts, N. (1996), Lead isotope data from the Isotrace Laboratory, Oxford: Archaeometry data base 3, ores from the Aegean, part 1, Archaeometry 38, 381-390.

Tadmor, M., Kedem, D., Begemann, F., Hauptmann, A., Pernicka, E., and Schmitt-Strecker, S. (1995), The Nahal Mishmar Hoard from the Judean Desert: technology, composition, and provenance, Atiqot 27, 95-148.

Vavelidis, M., Bassiakos, I., Begemann, F., Patriarcheas, K., Pernicka, E., Schmitt-Strecker, S., and Wagner, G.A. (1985), Geologie und Erzvorkommen, in G.A. Wagner and G. Weisgerber, eds., Silber, Blei und Gold auf Siphnos - Prähistorische und antike Metallproduktion, Bochum, pp. 5980.

Verly, G. and Rademakers, F.W. (forthcoming), La chaîne opératoire spécifique métallurgique d'Ayn Soukhna au Moyen Empire: métallurgie primaire, métallurgie secondaire, production de cuivre et d'outils en alliage cuivreux, in C. Somaglino, G. Castel, and P. Tallet, Ayn Soukhna V. Etudes sur la zone d'habitat et d'activités artisanales du site (1), rapport archéologique, Cairo: IFAO.

Wagner, G.A., Wagner, I., Öztunali, Ö., Schmitt-Strecker, S., and Begemann, F. (2003), Archäometallurgischer Bericht über Feldforschung in Anatolien und bleiisotopische Studien an Erzen und Schlacken, in T. Stöllner, G. Körlin, G. Steffens, and J. Cierny, eds., Man and Mining (Mensch und Bergbau), Bochum: Deutsches Bergbau-Museum, pp. 475-494.

Wagner, G.A., Pernicka, E., Seeliger, T.C., Lorenz, I.B., Begemann, F., Schmitt-Strecker, S., Eibner, C., and Öztunali, Ö. (1986), Geochemische und isotopische Charakteristika früher 
Rohstoffquellen für Kupfer, Blei, Silber und Gold in der Türkey, Jahrbuch des RömischGermanischen Zentralmuseums Mainz 33, 723-752.

Wagner, G.A., Pernicka, E., Seeliger, T.C., Öztunali, Ö., Baranyi, I., Begemann, F., and SchmittStrecker, S. (1985), Geologische Untersuchungen zur Fruhen Metallurgie in NW-Anatolien, Bulletin of the Mineral and Exploration Institute of Turkey 100-101, 45-81.

Weeks, L. (1997), Prehistoric metallurgy at Tell Abraq, U.A.E., Arabian Archaeology and Epigraphy 8, 11-85.

Weeks, L. (1999), Lead isotope analyses from Tell Abraq, United Arab Emirates: new data regarding the 'tin problem' in Western Asia, Antiquity 73, 49-64.

Weeks, L. (2003), Early Metallurgy of the Persian Gulf, Boston/Leiden: Brill Academic Publishers, Inc.

Yener, K.A., Sayre, E.V., Joel, E.C., Özbal, H., Barnes, I.L., and Brill, R.H. (1991), Stable lead isotope studies of Central Taurus ore sources and related artifacts from eastern Mediterranean Chalcolithic and Bronze Age sites, Journal of Archaeological Science 18, 541-577.

Zoheir, B.A., Johnson, P.R., Goldfarb, R.J., and Klemm, D.D. (2019), Orogenic gold in the Egyptian Eastern Desert: widespread gold mineralization in the late stages of Neoproterozoic orogeny, Gondwana Research 75, 184-217. 